\title{
Complement component C3a plays a critical role in endothelial activation and leukocyte recruitment into the brain
}

Fengjiao $\mathrm{Wu}^{1 \dagger}$, Qiang Zou ${ }^{2 \dagger}$, Xiaodan Ding ${ }^{1}$, Dongyan Shi', Xingxing Zhu', Weiguo Hu${ }^{3}$, Lixin $\mathrm{Liu}^{4}$ and Hong Zhou ${ }^{1 *}$

\begin{abstract}
Background: The complement system is becoming increasingly recognized as a key participant in many neurodegenerative diseases of the brain. Complement-deficient animals exhibit reduced neuroinflammation.

Methods: In the present study, we administered intracerebroventricularly lipopolysaccharide (LPS) to mimic local infection of the brain and investigated the role of key complement component C3 in brain vasculature endothelial activation and leukocyte recruitment. The degree of neutrophil infiltration was determined by esterase staining. Leukocyte-endothelial interactions were measured using intravital microscopy. Cerebral endothelial activation was evaluated using real-time PCR and Western blotting.

Results: Neutrophil infiltration into the brain cortex and hippocampus was significantly reduced in $\mathrm{C}^{-/-}$mice and $\mathrm{C} \mathrm{aR}^{-/-}$mice but not in $\mathrm{C}^{-1-}$ mice. We detected markedly attenuated leukocyte-endothelial interactions in the brain microvasculature of $\mathrm{C}^{-1-}$ mice. Accordingly, in response to LPS administration, the brain microvasculature in these mice had decreased expression of P-selectin, E-selectin, intercellular cell adhesion molecule 1 (ICAM-1), and vascular cell adhesion molecule 1 (VCAM-1). Depletion of C3 from the circulation also caused reduction in VCAM-1 and Eselectin expression and leukocyte recruitment, suggesting that C3 in the circulation contributed to brain endothelial activation. Furthermore, $\mathrm{C}^{-/-}$mice exhibited decreased leukocyte recruitment into the brain upon tumor necrosis factor-a (TNF-a) stimulation. C3a activated the phosphorylation of p38 mitogen-activated protein kinase (MAPK) and nuclear factor-KB (NF-KB) and induced the upregulation of VCAM-1 and ICAM-1 expression in murine primary cerebral endothelial cells in vitro.
\end{abstract}

Conclusions: Our study provides the first evidence that C3a plays a critical role in cerebral endothelial activation and leukocyte recruitment during inflammation in the brain.

Keywords: Complement, CNS inflammation, Intravital microscopy, Adhesion molecule, Leukocyte recruitment

\section{Background}

Although the brain is considered to be an immuneprivileged organ $[1,2]$, devastating effects can occur in the brain during local inflammation, particularly in response to cerebral bacterial infection. The recruitment of immune cells from the circulation is critical for many lifethreatening central nervous system (CNS) inflammatory

\footnotetext{
* Correspondence: hzhou@njmu.edu.cn

${ }^{\dagger}$ Equal contributors

'Department of Immunology, Nanjing Medical University, 140 Hanzhong

Road, Nanjing, JS 210029, China

Full list of author information is available at the end of the article
}

diseases, such as bacterial meningitis [3], multiple sclerosis [4], and stroke [5]. Neutrophils mobilized from the circulation in response to signals from the CXC family of chemokines, such as keratinocyte-derived chemokine (KC, CXCL1), and macrophage inflammatory protein-2 (MIP2, CXCL2), are considered to be the first line of defense against bacteria [6-9]. Once activated through cytokines, such as tumor necrosis factor- $\alpha$ (TNF- $\alpha$ ) and interferon- $\gamma$ (IFN- $\gamma)$, endothelial cells upregulate adhesion molecule expression, which enhances their interactions with the leukocytes and increases their transmigration into the brain $[10,11]$. Neutrophils have been identified as the key 
players in CNS inflammation, and strategies that block neutrophil recruitment have been demonstrated as beneficial for the treatment of many types of CNS inflammation [12-14]. In a previous study, we showed that microglia play a dominant role in the innate immune response to infectious agents in the CNS [15]. Additionally, it has been widely accepted that inflammatory cytokines, such as TNF- $\alpha$ and chemokines from glial cells, activate the endothelium, thereby increasing adhesion molecule expression and leukocyte recruitment [16-18].

The complement system consists of approximately 40 soluble and membrane-bound proteins that play a central role in host defense against pathogens and inflammation initiation $[19,20]$. Although the liver is the primary source of complement production, increasing evidence from recent studies has shown that many types of resident cells in the CNS produce complement components [21]. The expression of complement receptors, such as the C3a and C5a receptors on glial cells and neurons in the CNS, has been reported [22, 23]. Further studies in animal models have provided evidence for the involvement of the complement system in modulating CNS inflammation [24, 25]. In particular, systemic complement depletion reduces perihematomal brain edema and TNF- $\alpha$ production following experimental intracerebral hemorrhage [26]. Moreover, $\mathrm{C}^{-/-}$mice exhibited less brain edema and less microglial activation and neutrophil infiltration around the clot after intracerebral hemorrhage [27]. In a mouse model of meningitis induced by Streptococcus pneumonia infection, $\mathrm{C} 1 \mathrm{q}$ and $\mathrm{C} 3$ deficiency led to reduced cerebrospinal fluid (CSF) leukocyte counts in comparison with infected wild-type (WT) mice [28]. Additionally, mice lacking $\mathrm{C} 3$ and its receptors developed increased burdens of West Nile virus in the CNS [29]. C5a receptordeficient mice with pneumococcal meningitis also showed lower CSF leukocyte counts and alleviated brain damage compared with WT mice. Moreover, treatment with C5specific monoclonal antibodies prevented animal death in WT mice with pneumococcal meningitis [30]. These studies suggest that the complement system plays a significant role in the CNS inflammatory response. However, the mechanisms underlying the contribution of complement components to immune cell recruitment into the brain parenchyma through the blood-brain barrier (BBB) remain unclear.

In this study, we systemically examined the detailed mechanisms underlying the contribution of complement components to leukocyte recruitment in response to cerebral lipopolysaccharide (LPS) administration. We first detected significantly reduced infiltrating neutrophils in the brain of $\mathrm{C} 3$-deficient $\left(\mathrm{C}^{-/-}\right)$and $\mathrm{C} 3 \mathrm{a}$ receptor-deficient $\left(\mathrm{C} \mathrm{aR}^{-/-}\right)$but not C6-deficient $\left(\mathrm{C6}^{-/-}\right)$mice. $\mathrm{C} 3$ deficiency also significantly reduced endothelial activation and leukocyte-endothelial interactions in brain postcapillary venules. Permeability changes in the $\mathrm{BBB}$ were comparable between WT and $\mathrm{C}^{-/-}$mice. Adhesion molecules, such as E-selectin and vascular cell adhesion molecule 1 (VCAM-1), showed reduced expression levels in the brains of $\mathrm{C}^{-/-}$mice in response to LPS administration, suggesting that $\mathrm{C} 3$ contributes to the activation of brain endothelium. Furthermore, TNF- $\alpha$ was not able to induce leukocyte recruitment in $\mathrm{C}^{-1-}$ mice. C3a directly stimulated cerebral endothelial activation in vitro. Taken together, these results demonstrate that C3a plays a critical role in endothelial activation and subsequent leukocyte recruitment in the brain in response to intracerebroventricular LPS administration.

\section{Methods}

\section{Animals}

Adult male wild-type (WT) C57BL/6J and BALB/c mice 7 to 8 weeks old weighing 20 to $25 \mathrm{~g}$ were obtained from the Model Animal Research Center, Nanjing University. C3deficient $\left(\mathrm{C}^{-/-}\right)$mice (C57BL/6J mice background) and C3a receptor-deficient $\left({\mathrm{C} 3 a R^{-/-}}^{-}\right)$mice $(\mathrm{BALB} / \mathrm{c}$ mice background) were purchased from the Jackson Laboratory (Bar Harbor, ME, USA). The $\mathrm{C}^{\mathrm{a} \mathrm{R}^{-/-}}$mice $(\mathrm{C} 57 \mathrm{BL} / 6 \mathrm{~J}$ background) were obtained from Dr. Hu Weiguo (Shanghai Cancer Center and Institute of Biomedical Science, Shanghai Medical College, Fudan University, China). The C6-deficient $\left(\mathrm{C6}^{-/-}\right)$mice $(\mathrm{C} 57 \mathrm{BL} / 6 \mathrm{~J}$ mice background) were a gift from Dr. Tod Merkel (Center for Biologics Evaluation and Research, Food and Drug Administration, USA). The animals were housed under a 12-h light/dark cycle under specific pathogen-free conditions with free access to food and water. All animal protocols were reviewed and approved by the Institutional Animal Care and Use Committee of Nanjing Medical University. All animal experiments were carried out in a blinded and randomized fashion.

\section{Intracerebroventricular LPS injection}

The mice were anesthetized using an intraperitoneal (i.p.) injection of $200 \mathrm{mg} / \mathrm{kg}$ of ketamine and $10 \mathrm{mg} / \mathrm{kg}$ of xylazine. Subsequently, the mice were placed onto a rodent stereotaxic frame (David Kopf Instruments, Tujunga, CA, USA). The scalp was shaved, and a burr hole was drilled $1 \mathrm{~mm}$ caudal to the bregma and $2.0 \mathrm{~mm}$ lateral to the midline [15, 31]. A total of $2 \mu \mathrm{L}$ of $2 \mu \mathrm{g}$ of LPS (Escherichia coli serotype 0111:B4 strain; InvivoGen) or $0.2 \mu \mathrm{g}$ of TNF$\alpha$ (R\&D systems, Minneapolis, MN, USA) was administered by intracerebroventricular (i.c.v.) injection using a 10- $\mu \mathrm{l}$ Hamilton microsyringe over a 3-min period. Control animals received an isovolumetric i.c.v. injection of saline. Body temperature was monitored using a rectal probe, and the mice were maintained under deep anesthesia at $36 \pm$ $1{ }^{\circ} \mathrm{C}$ using a thermostatic heating system (Harvard Apparatus, MA, USA) throughout the experiment. 


\section{Immunohistochemical procedure}

Mice under deep anesthesia and received i.c.v. LPS or saline injection were perfused through the heart with ice-cold $4 \%$ formalin. The cerebral tissues were then removed and fixed in $4 \%$ formalin for $48 \mathrm{~h}$. Thick coronal sections were obtained at -1.0 to $-3.0 \mathrm{~mm}$ from the bregma. Formalin-fixed tissues were embedded in paraffin and subsequently sectioned at a $4-\mu \mathrm{m}$ thickness using a cryostat. Infiltrating neutrophils were detected using a Naphthol AS-D Chloroacetate-Specific Esterase kit (Sigma-Aldrich, St. Louis, MO, USA).

\section{Intravital microscopy}

The animals were anesthetized and monitored as described previously [15]. A craniotomy was performed using a high-speed drill in the right parietal bone. Stripping the dura from the site exposed the brain pial vessels. Subsequently, the animals were intravenously (i.v.) administered rhodamine 6G (Sigma-Aldrich) $(0.5 \mathrm{mg} / \mathrm{kg}$, body weight) to label leukocytes. Leukocyte-endothelial interactions were recorded using an sCMOS camera (ORCAFlash 4.0, HAMAMATSU) mounted onto a Nikon FN1 microscope. Three different postcapillary venules with diameters between 30 and $70 \mu \mathrm{m}$ were chosen for observation. All experiments were recorded for subsequent playback analysis. Rolling leukocytes were defined as cells moving at a velocity less than that of erythrocytes. Cells remaining stationary for at least $30 \mathrm{~s}$ were considered adherent.

\section{Blood-brain barrier permeability determination}

The levels of albumin, a plasma protein that is normally excluded from the brain by the intact BBB, were used as an indicator for its integrity. The mice were anesthetized and perfused with $20 \mathrm{ml}$ of ice-cold phosphate-buffered saline (PBS) to remove contaminated albumin from the circulation. Then, the concentration of albumin in brain homogenates was measured by Western blotting as previously described [32].

\section{Complement depletion}

Four hours prior to i.c.v. LPS injection, hypocomplementemia was induced through the i.p. injection of cobra venom factor (CVF) (Biogen Sci \& Tech Co., Kunming, China) in PBS into C57BL/6J mice at a dose of $10 \mu \mathrm{g} /$ mouse ( $15 \mathrm{U} /$ mouse). This treatment depletes complement within $4 \mathrm{~h}$ of the injection, reducing the levels of $\mathrm{C} 3$ in the circulation to less than $3 \%$ of the normal range, which persists for at least $48 \mathrm{~h}$ postinjection [33, 34].

\section{RNA isolation and real-time quantitative PCR}

Total RNA was extracted from brain tissue using Trizol reagent (Invitrogen, Carlsbad, CA, USA) and was then reversely transcribed using Superscript II (Invitrogen, Carlsbad, CA, USA). Real-time PCR was performed using a SYBR green PCR reagent according to the manufacturer's instructions (Applied Biosystems, Yerevan, Armenia). The following DNA sequences were used for the primer pairs: P-selectin forward primer, 5'-TCCAGGAAGCTCTGACG TACTTG-3'; P-selectin reverse primer, 5'-GCAGCGTT AGTGAAGACTCCGTAT-3'; E-selectin forward primer, 5'-TGAACTGAAGGGATCAAGAAGACT-3'; and E-selectin reverse primer, 5'-GCCGAGGGACATCATC ACAT-3'; VCAM-1 forward primer, 5'-TGACAAGTC CCCATCGTTGA-3'; and VCAM-1 reverse primer, 5'-ACCTCGCGACGGCATAATT-3'; intercellular cell adhesion molecule (ICAM-1) forward primer, $5^{`}$-CC TGTTTCCTGCCTCTGAAG-3'; and ICAM-1 reverse primer, 5'-GTCTGCTGAGACCCCTCTTG-3'. Mouse $\beta 2$-microglobulin $\left(\beta_{2}-\mathrm{MG}\right)$ was used as an internal control with the following primer sequences: $\beta_{2}$-MG forward primer, 5'-CCTGCAGAGTTAAGCATGACAGT-3'; and $\beta_{2}$-MG reverse primer, 5'-TCATGATGCTTGATCACAT GTCT-3'. Quantitative PCR was performed with an ABI Prism 7300 spectrofluorometric thermal cycler (Applied Biosystems) using SYBR Green I as a double-stranded DNA-binding dye. The amplification conditions consisted of $95{ }^{\circ} \mathrm{C}(2 \mathrm{~min})$, followed by 32 cycles of $95{ }^{\circ} \mathrm{C}(20 \mathrm{~s})$, $57.2{ }^{\circ} \mathrm{C}(30 \mathrm{~s})$, and $72{ }^{\circ} \mathrm{C}(30 \mathrm{~s})$. Quantitative PCR assays were conducted in triplicate and were then quantitated using the $2^{-\Delta \Delta \mathrm{Ct}}$ method. The data are expressed as $n$-fold differences relative to the calibrator.

\section{Enzyme-linked immunosorbent assay}

The mice were anesthetized after LPS injection and subsequently perfused through the heart with cold PBS to remove blood proteins from the circulation. The brains were rapidly removed and homogenized in $1 \mathrm{ml}$ of sterile PBS, followed by centrifugation at 12,000 rpm for $5 \mathrm{~min}$ at $4{ }^{\circ} \mathrm{C}$. The supernatants were assayed for determining TNF- $\alpha$ and IL-1 $\beta$ concentrations using commercial enzyme-linked immunosorbent assay (ELISA) kits (TNF- $\alpha$, BD, San Diego, CA, USA; IL-1 $\beta$, eBioscience, San Diego, CA, USA) according to the manufacturers' instructions. To measure the levels of $\mathrm{C} 3 \mathrm{a}$ in brain and plasma of mice, plates were coated with $100 \mu \mathrm{l}$ of rat anti-mouse capture antibody specifically against C3a (BD Biosciences, San Jose, CA, USA) at 1:250 dilutions in PBS overnight at $4{ }^{\circ} \mathrm{C}$. FUT-175 (BD Biosciences) which was dissolved with $1 \mathrm{ml} d d^{2} \mathrm{H}_{2} \mathrm{O}$, a synthetic inhibitor for the classical and alternate pathways of complement activation, was added into the EDTA blood and brain samples according to the manufacturer's instructions. In details, $10 \mu \mathrm{l}$ of FUT-175 was added into $1 \mathrm{ml}$ of freshly drawn EDTA blood or brain supernatant on ice. After centrifugation, the plasma and brain proteins in these samples were collected for the ELISA assay. 
Brain, plasma samples, or C3a standard solution were diluted and added to the plates coated with capture antibody and incubated at room temperature for $2 \mathrm{~h}$, and purified mouse C3a protein (BD Bioscience) was set as standard. Brain and plasma samples from $\mathrm{C}^{-/-}$mice were set as negative control. After washing four times, $100 \mu \mathrm{l}$ of biotin-conjugated rat anti-mouse C3a (BD Biosciences) at 1:500 dilution in PBS with $10 \%$ FBS was added to each well and incubated at room temperature for $1 \mathrm{~h}$. The wells were washed again and then incubated with a 1:250 dilution of streptavidin/ horseradish peroxidase (HRP) (BD Biosciences) for $1 \mathrm{~h}$ at room temperature. The wells were washed, and $100 \mu \mathrm{l}$ of substrate solution (BD Biosciences) was added to each well. The color was developed for $10-20 \mathrm{~min}$ with the reaction stopped by the addition of $2 \mathrm{~N} \mathrm{H}_{2} \mathrm{SO}_{4}$. Absorbance was read at $450 \mathrm{~nm}$ with correction for absorbance at $550 \mathrm{~nm}$.

\section{Western blotting}

The complement factor $\mathrm{C} 3$ and albumin were analyzed in the brain homogenates and plasma samples obtained from experimental mice. To obtain the brain homogenates, the mice were anesthetized at 4,12 , and $24 \mathrm{~h}$ after i.c.v. LPS injection and subsequently perfused with ice-cold PBS to clear blood-borne proteins. Each brain was removed and homogenized in PBS on ice, followed by centrifugation at 12,000 rpm for $5 \mathrm{~min}$. For the analysis of plasma complement content, blood $(100-400 \mu \mathrm{l})$ was obtained by intracardiac puncture of anesthetized animals immediately prior to the perfusion. $10 \mu \mathrm{l}$ of FUT-175 (Futhan) was immediately added into each milliliter of the freshly drawn EDTA blood on ice. After centrifugation at $2500 \mathrm{rpm}$ for $10 \mathrm{~min}$, these plasma samples were boiled in loading buffer for another $10 \mathrm{~min}$. Subsequently, the samples were diluted and separated on a $10 \%$ acrylamide-

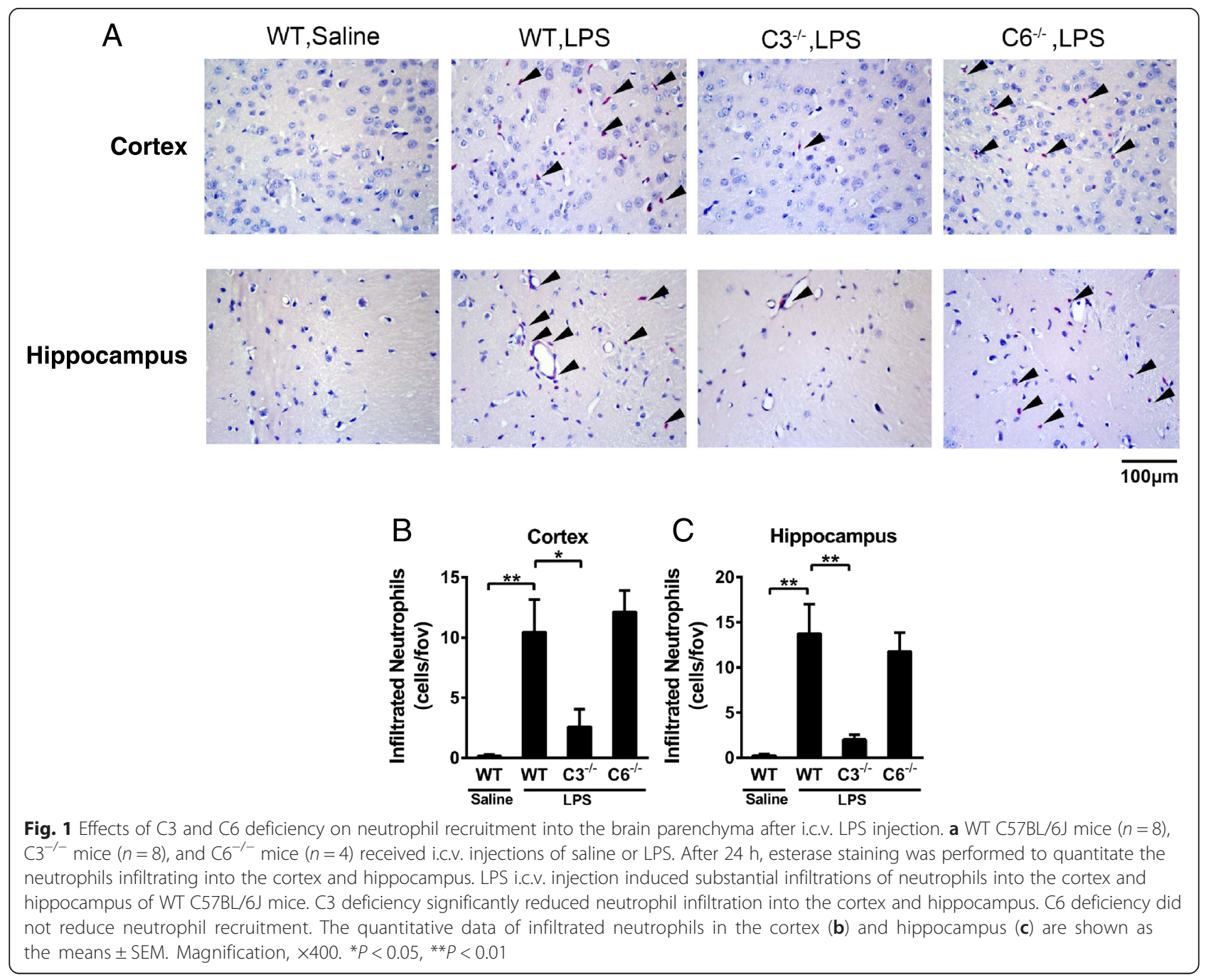


sodium dodecyl sulfate (SDS) gel, followed by transferring onto membranes and blotting overnight at $4{ }^{\circ} \mathrm{C}$ with the following antibodies: anti-C3 (Abcam, Cambridge, USA), anti-albumin (Abcam), anti-E-selectin (Abcam), antiVCAM-1 (Abcam), anti-ICAM-1 (Abcam), anti-GAPDH (Abcam), anti-NF-kB p65 (Cell Signaling Technology, Beverly, CA, USA), anti-phospho-NF-кB p65 antibody (Cell Signaling Technology), and anti- $\beta$-actin (Cell Signaling Technology). The membrane was washed $(0.05 \%$ Tween-20 in PBS), incubated with peroxidase-labeled goat anti-rabbit IgG or anti-goat IgG, and washed again. Antibody binding was visualized using enhanced chemiluminescence reagents (PerkinElmer, Waltham, MA, USA). Densitometric images were quantified using ImageJ software (National Institutes of Health, Bethesda, MD, USA). Relative expression levels of proteins were normalized to $\beta$-actin.

Isolation and culture of murine cerebral endothelial cells The mice were sacrificed, and their brains were collected. The cerebral cortices, devoid of cerebella, white matter, and leptomeninges, were minced into small pieces. The pellet was digested in $15 \mathrm{ml}$ of $0.1 \%$ collagenase B (Roche, Indianapolis, IN, USA) supplemented with $30 \mathrm{U} / \mathrm{ml}$ of DNase I (Sigma-Aldrich) for 1.5-2 h at $37{ }^{\circ} \mathrm{C}$ with occasional agitation. The microvessels were isolated through gradient centrifugation on $15 \%$ dextran (Sigma-Aldrich) and subsequently digested in $0.1 \%$ collagenase/dispase (Roche) supplemented with $20 \mathrm{U} / \mathrm{ml}$ of DNase I for $1.5-2 \mathrm{~h}$ at $37{ }^{\circ} \mathrm{C}$ with occasional agitation. The microvessel pellets were resuspended in medium supplemented with $3 \mathrm{ng} / \mathrm{ml}$ of bovine fibroblast growth factor (bFGF, Peprotech, Rocky Hill, NJ, USA), $30 \%$ fetal bovine serum (FBS), $10 \mathrm{U} / \mathrm{ml}$ of heparin, $100 \mathrm{U} / \mathrm{ml}$ of penicillin, and $100 \mathrm{mg} / \mathrm{ml}$ of streptomycin. The microvessel suspension was plated onto 6-well plates coated with rat-tail collagen I (Sigma-Aldrich) and incubated at $37{ }^{\circ} \mathrm{C}$ with $5 \% \mathrm{CO}_{2}$. The medium was changed every 2 days. The endothelial cells began migrating from the vessels within $2-3$ days and grew to confluence within 7-10 days.

\section{Statistical analysis}

Statistical analysis was performed using SPSS software (17.0 for Windows, IBM Inc., Chicago, IL, USA). The values are expressed as the means \pm standard errors of the mean (SEM). Differences between the two groups were analyzed using Student's $t$ test, and $P<0.05$ was considered significant.

\section{Results}

C3 deficiency decreases LPS-induced neutrophil recruitment into the brain

To examine the roles of complement components in neutrophil recruitment into the CNS, WT C57BL/6J mice, $\mathrm{C}^{-/-}$mice, and $\mathrm{C}^{-1-}$ mice were subjected to i.c.v.

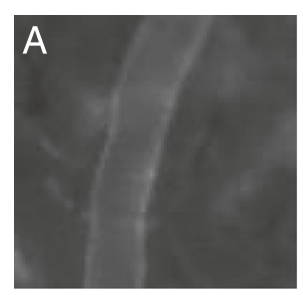

WT, Saline

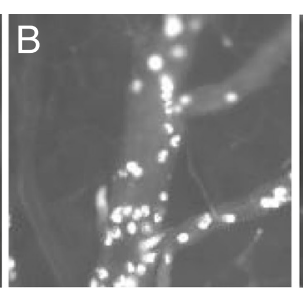

WT, LPS

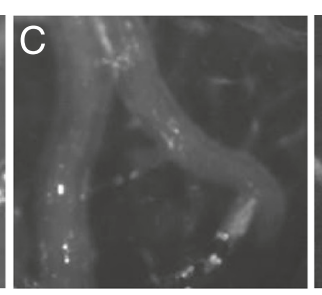

C3 ${ }^{-1}$, LPS

F

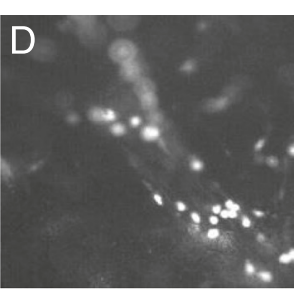

C6 ${ }^{-/}$, LPS
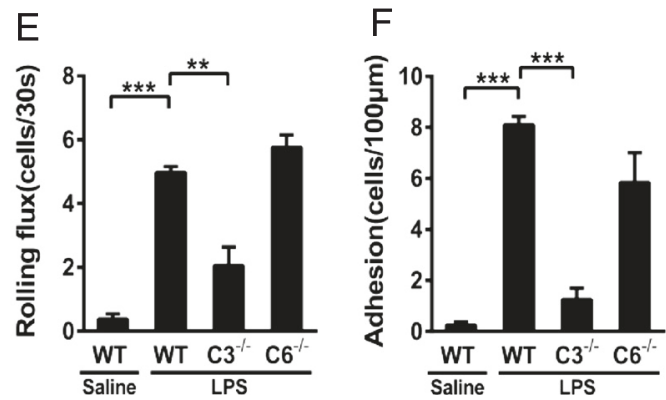

Fig. 2 Leukocyte-endothelial interactions in WT and $C 3^{-/-}$and $C 6^{-1-}$ mice after i.c.v. LPS injection. WT C57BL/6J mice and C ${ }^{-1-}$ and C6 ${ }^{-/-}$mice received i.c.v. injections of LPS or saline, and leukocyte-endothelial interactions were examined through intravital microscopy. a WT C57BL/6J mice with saline injection showed no evident recruitment into CNS vessels. After i.c.v. injection of LPS, WT C57BL/6J mice with LPS injection showed significant recruitment into CNS vessels $(\mathbf{b})$, and $\mathrm{C}^{-/-}$mice exhibited reduced recruitment into the CNS (c). $\mathbf{d}$ C6 ${ }^{-1-}$ mice exhibited leukocyteendothelial interactions comparable with those observed in WT mice. The numbers of rolling (e) and adhesive cells (f) are shown as the means $\pm \mathrm{SEM} ; n=6$ for all groups, ${ }^{* *} P<0.01,{ }^{* *} p<0.001$ 
LPS injection. Brain sections from these mice were stained with esterase to evaluate neutrophil recruitment. In response to LPS, neutrophils initiated extravasation into the brain at $12 \mathrm{~h}$ post-injection, and infiltration peaked at $24 \mathrm{~h}$ in the cortex and hippocampus and subsequently decreased. Compared with WT mice, the number of neutrophils infiltrated into the brain cortex and hippocampus was significantly reduced in $\mathrm{C}^{-/-}$but not $\mathrm{C}^{-/-}$mice (Fig. 1a-c).

Using intravital microscopy, we further examined the roles of complement components in leukocyte-endothelial interactions in postcapillary venules in the CNS. The i.c.v. administration of saline did not induce leukocyte rolling and adhesion in brain postcapillary venules of WT mice (Fig. 2a). The i.c.v. administration of LPS induced significant leukocyte rolling and adhesion in brain postcapillary venules of WT mice (Fig. 2b, Additional file 1). Consistent with the immunohistochemical results, leukocyte recruitment in brain vessels was significantly reduced in the brain venules of $\mathrm{C}^{-/-}$(Fig. 2c, Additional file 2) but not $\mathrm{C6}^{-1-}$ mice (Fig. 2d, Additional file 3) at $4 \mathrm{~h}$ postinjection. Rolling (Fig. 2e) and adherent leukocytes (Fig. 2f) were quantified in WT, $\mathrm{C}^{-/-}$, and $\mathrm{C}^{-1-}$ mice. Taken together, these results suggest that neutrophil recruitment

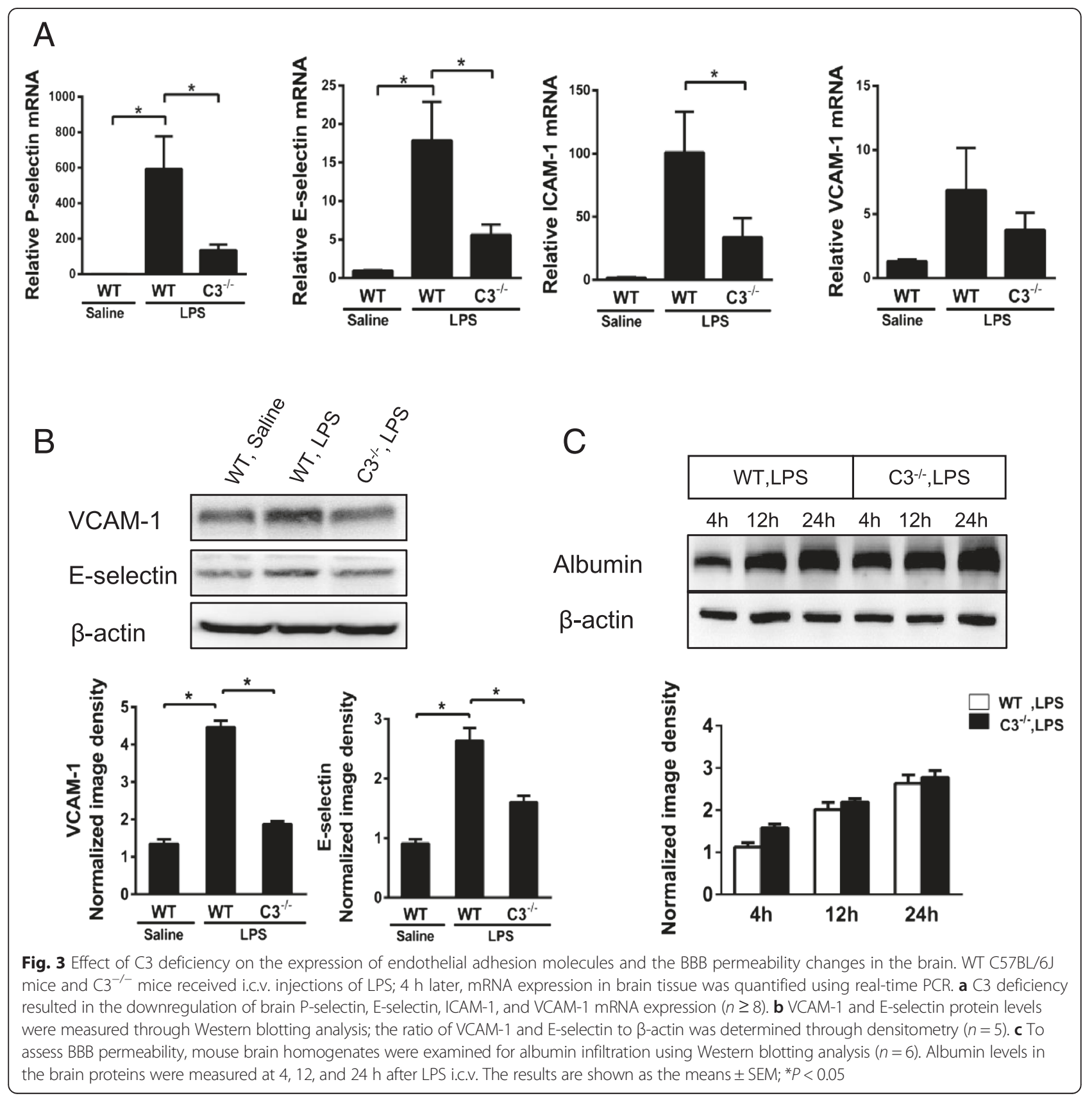



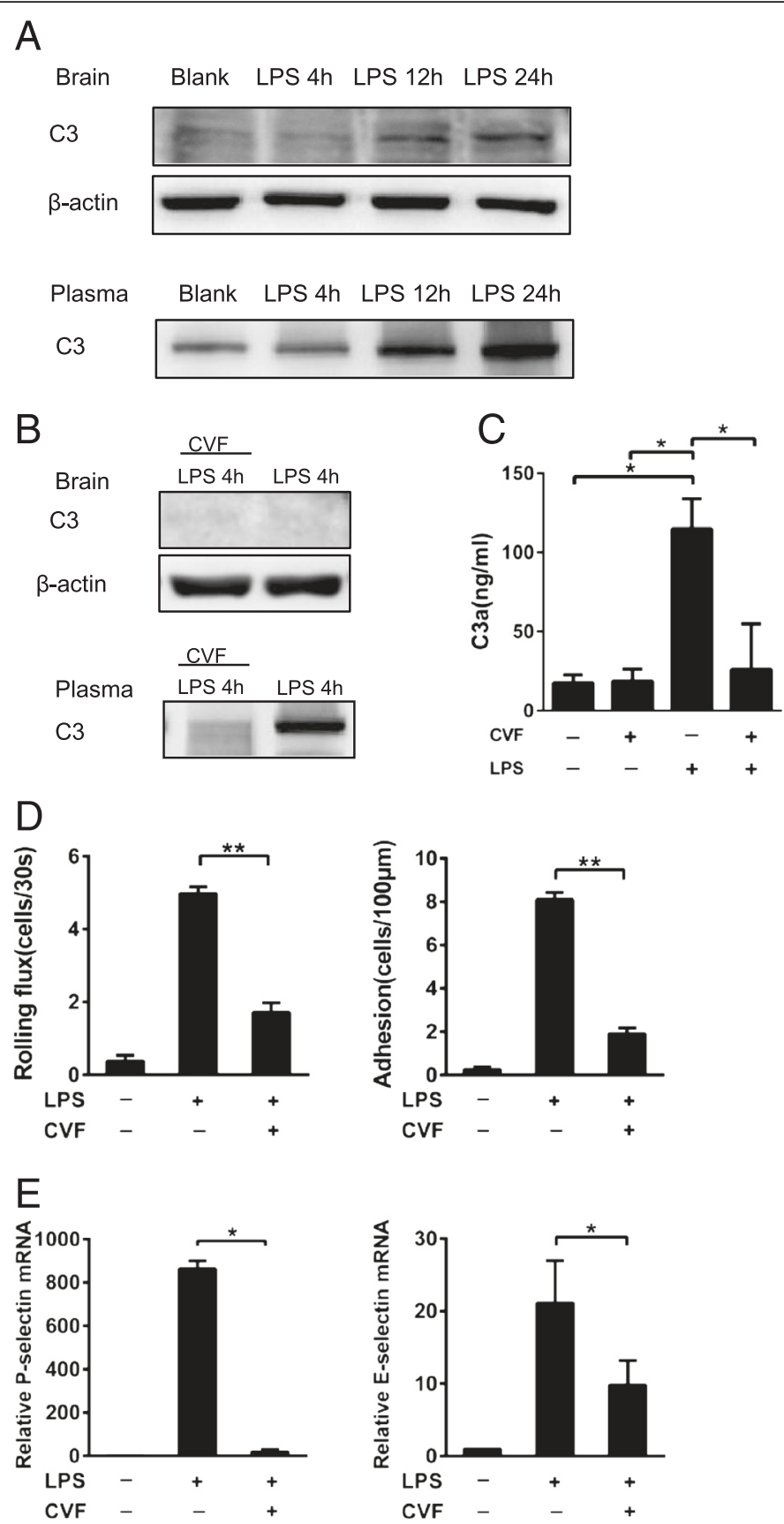

$\mathrm{F}$
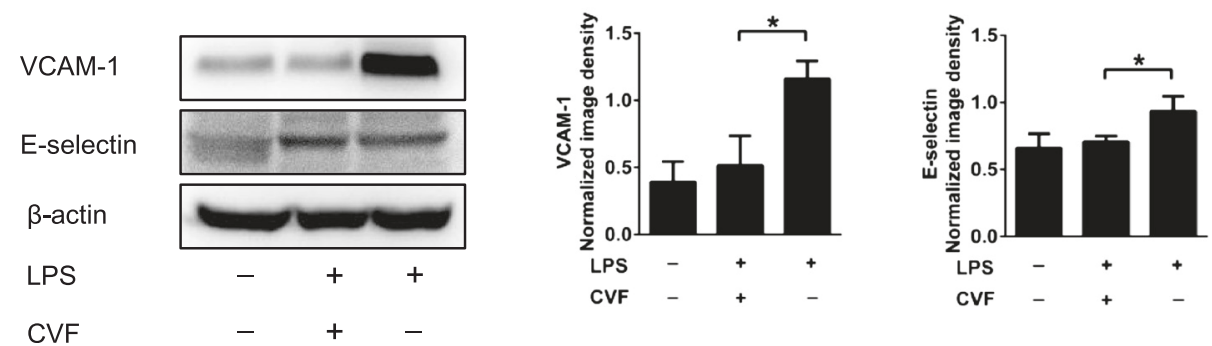

Fig. 4 (See legend on next page.) 
(See figure on previous page.)

Fig. 4 Effects of complement depletion on leukocyte recruitment into the brain parenchyma after i.c.v. LPS injection. a WT C57BL/6J mice were treated i.c.v. with LPS, and C3 levels in the brain (without dilution, cleared from blood proteins) and plasma (diluted in 1:100) were determined by Western blotting. b WT C57BL/6J mice received i.p. injections of CVF (10 $\mu \mathrm{g} / \mathrm{mouse})$ or PBS. After 4 h, WT C57BL/6J mice $(n=4)$ received i.c.v. LPS injection, and after $4 \mathrm{~h}$, plasma and brain samples were then collected for C3 Western blotting analysis. At $4 \mathrm{~h}$ after CVF injection, WT C57BL/6J mice $(n=4)$ received i.c.V. LPS injection, and plasma samples were collected for C3a ELISA assay (c). At $4 \mathrm{~h}$ after i.p. injection of CVF to deplete complement from the blood circulation, mice received i.c.v. LPS injection. Then, after 4 h, rolling and adhesion leukocytes were quantified using intravital microscopy $(\mathbf{d})$. e P-selectin and E-selectin mRNA expressions were measured using real-time PCR. $\mathbf{f}$ VCAM-1 and E-selectin protein levels in the brain were examined by Western blotting $(n=4)$. Images are representative of four experiments. The ratio of VCAM-1 and E-selectin to $\beta$-actin was determined through densitometry. The results are shown as the means \pm SEM. ${ }^{*} P<0.05,{ }^{* *} P<0.01 ; n \geq 4$ for all groups

induced through i.c.v. LPS administration requires C3 but not C6.

\section{C3 deficiency decreases LPS-induced brain endothelial adhesion molecule expression but not permeability changes}

Adhesion molecules primarily mediate leukocyteendothelial interactions and are markers of endothelial activation in acute inflammation $[35,36]$. To determine whether $\mathrm{C} 3$ deficiency influenced endothelial activation, we examined the mRNA expression levels of different adhesion molecules upon LPS injection in $\mathrm{C}^{-/-}$mice. C3 deficiency resulted in significant reduced P-selectin, E-selectin, ICAM-1, and VCAM-1 transcription in the brain at $4 \mathrm{~h}$ after LPS injection (Fig. 3a). Moreover, Western blotting analysis also revealed the reduced expression of VCAM-1 and E-selectin in the brain of $\mathrm{C}^{-/-}$mice (Fig. 3b).

BBB permeability profoundly affects leukocyte recruitment in the brain. To examine whether C3 deficiency led to altered $\mathrm{BBB}$ permeability, we measured the brain concentrations of albumin leaked from the circulation into the brain tissues in LPS-treated WT and $\mathrm{C}^{-/-}$ mice. The i.c.v. injection of LPS induced time-dependent increases in $\mathrm{BBB}$ permeability. However, there was no significant difference in the permeability between WT and $\mathrm{C}^{-1-}$ mice (Fig. 3c). Taken together, these data suggest that reduced endothelial adhesion molecule expression caused by lower grade of endothelial activation, but not the altered brain $\mathrm{BBB}$ permeability, led to the reduced neutrophil recruitment in $\mathrm{C}^{-1-}$ mice. Clearly, C3 deficiency affected the activation of the brain endothelium upon LPS challenge.

\section{C3 depletion from circulation affected leukocyte recruitment in the brain}

Virtually all complement components can be locally produced in the CNS in response to injury or inflammation [21]. To determine the source of C3, which plays a major role in endothelial activation, we assessed the C3 levels in the CNS and blood circulation. C3 was virtually undetectable in the brain parenchyma at $4 \mathrm{~h}$ post-i.c.v. injection of LPS. Thereafter, C3 levels in the brain parenchyma progressively increased from 4 to $24 \mathrm{~h}$, peaking at $24 \mathrm{~h}$ after LPS injection (Fig. 4a). The plasma levels of
C3 remained stable in the first $12 \mathrm{~h}$ and thereafter increased progressively from 12 to $24 \mathrm{~h}$ after LPS treatment (Fig. 4a). Notably, the C3 levels in the circulation were significantly higher than those in the CNS, even after a 100-fold dilution of the plasma sample (Fig. 4a).

We examined leukocyte recruitment in mice at $4 \mathrm{~h}$ after receiving i.c.v. injection of LPS when C3 levels were depleted from the circulation by using CVF. CVF treatment depleted $95 \%$ of the C3 in circulation after $4 \mathrm{~h}$ (Fig. 4b). However, C3 levels in the brain at $4 \mathrm{~h}$ after the CVF treatment were very low and not affected by CVF (Fig. 4b). The plasma levels of C3a were increased significantly at $4 \mathrm{~h}$ after LPS treatment. CVF treatment depleted the majority of C3a in these LPS-treated animals (Fig. 4c). C3 depletion from the circulation significantly reduced rolling and adhesion (Fig. 4d) of leukocytes in brain vessels. Furthermore, CVF treatment significantly reduced the levels of LPS-stimulated P-selectin and Eselectin (Fig. 4e) mRNA expression in the brain. Additionally, CVF treatment reduced the protein levels of VCAM-1 significantly, and also reduced E-selectin slightly in LPStreated mouse brains (Fig. 4f).

\section{C3a and C3aR participate in leukocyte recruitment into the cerebral microvessels}

$\mathrm{C} 3 \mathrm{a}$, the cleavage product of $\mathrm{C} 3$, is an anaphylatoxin that triggers an inflammatory response engaging many types of cells to release cytokines and other inflammatory mediators. Upon i.c.v. LPS administration, the levels of C3a in the plasma were gradually increased at $4 \mathrm{~h}$ and substantially further increased at 12 and $24 \mathrm{~h}$ (Fig. 5a). In contrast, the C3a level in the brain parenchyma remained only marginally increased during this period (Fig. 5a). C3a acts on the receptor $\mathrm{C} 3 \mathrm{aR}$ to exert its biological functions [37, 38]. Using intravital microscopy, we further observed that LPS i.c.v. injection caused very limited rolling and adhesive (Fig. 5b) leukocytes in cerebral vasculature of $\mathrm{C} \mathrm{aR}^{-/-}$mice compared to the WT BALB/C mice. Intravital microscopy revealed similar levels of leukocyte-endothelial interactions in LPS-treated $\mathrm{C}_{5} \mathrm{aR}^{-/-}$ mice, as compared to LPS-treated WT C57BL/6J mice (Fig. 5c). These results further confirmed that C3a and $\mathrm{C} 3 \mathrm{aR}$, but not $\mathrm{C} 5 \mathrm{a}$ or $\mathrm{C} 5 \mathrm{aR}$, is essential for endothelial 

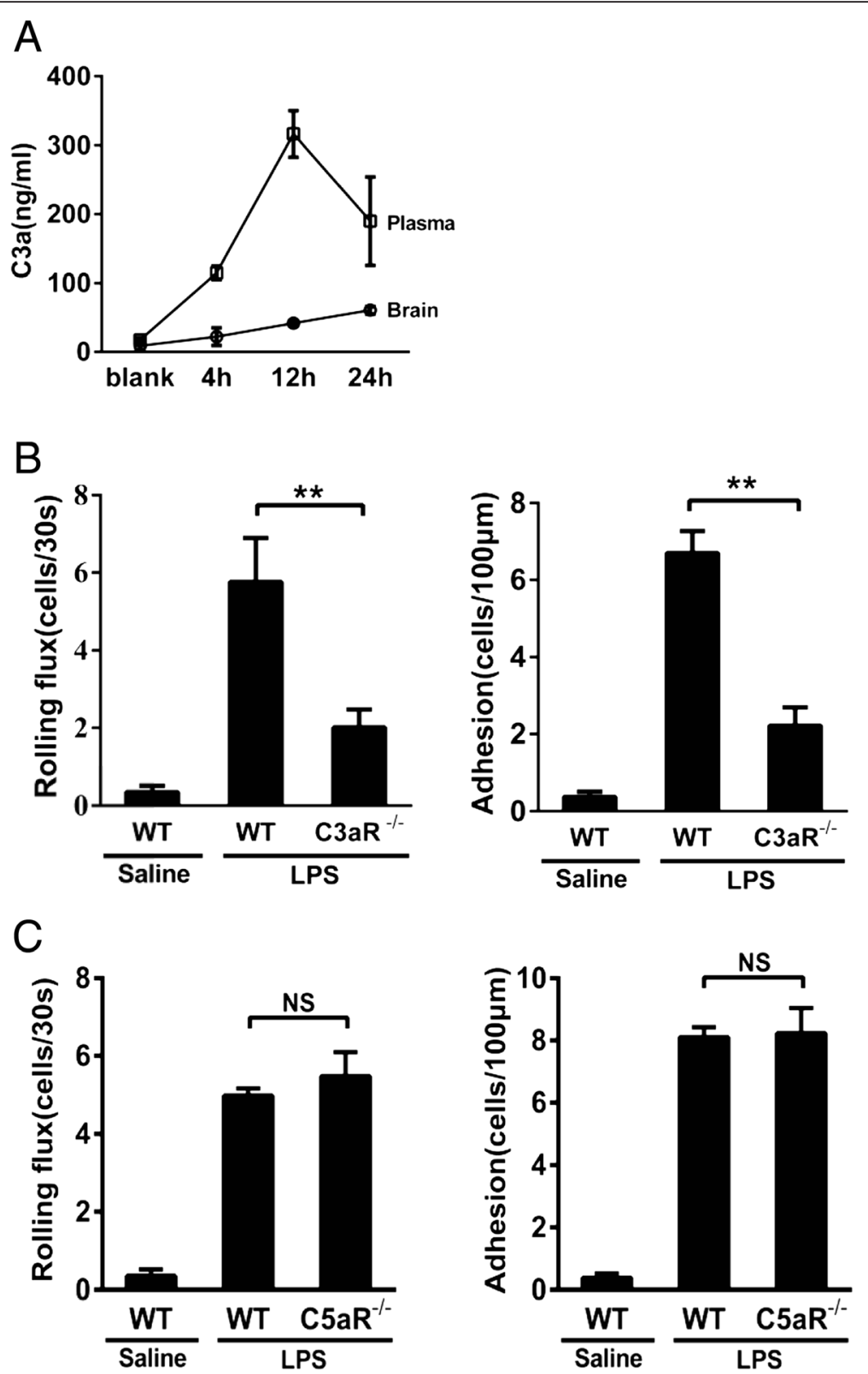

Fig. 5 The C3a receptor is essential for LPS-induced leukocyte recruitment into the brain vasculature. a WT C57BL/6J mice were i.c.V.-treated with LPS, and C3a levels in brain and plasma were then measured at $0,4,12$, and $24 \mathrm{~h}$ after LPS injection by ELISA. WT BALB/C mice, C3aR ${ }^{-1-}$ mice, WT C57BL/6J mice, and C5aR ${ }^{-/-}$mice were i.c.v.-treated with LPS, and $4 \mathrm{~h}$ later, intravital microscopy was performed. Leukocyte rolling flux and adhesion (b-c) are shown as the means \pm SEM. ${ }^{* *} P<0.01 ; n \geq 4$ for all groups

activation and subsequent leukocyte-endothelial interactions in the brain inflammation.

C3 was essential for TNF-a-induced cerebral endothelialleukocyte interactions in vivo

To determine whether the reduced leukocyte recruitment observed in $\mathrm{C}^{-/-}$mice was indicative of defective inflammatory cytokine production, we measured the levels of the inflammatory cytokines TNF- $\alpha$ and IL- $1 \beta$ in the brain of the mice i.c.v.-treated with LPS. Interestingly, the TNF- $\alpha$ levels in the brain were comparable in $\mathrm{WT}$ and $\mathrm{C} 3^{-/-}$ mice (Fig. 6a, $P>0.05$ ), whereas the IL-1 $\beta$ levels were significantly reduced only after $24 \mathrm{~h}$ in $\mathrm{C}^{-/-}$mice (Fig. 6b).

High levels of inflammatory cytokines (Fig. 6a, b) and chemokines (data not shown) were detected in the brain, while cerebral endothelial cells were not fully activated in the absence of C3. Furthermore, we administered i.c.v. injections of TNF- $\alpha$ into $C 3^{-1-}$ mice and observed that leukocyte rolling and adhesion were significantly reduced compared with WT mice (Fig. 6c, d). This result 

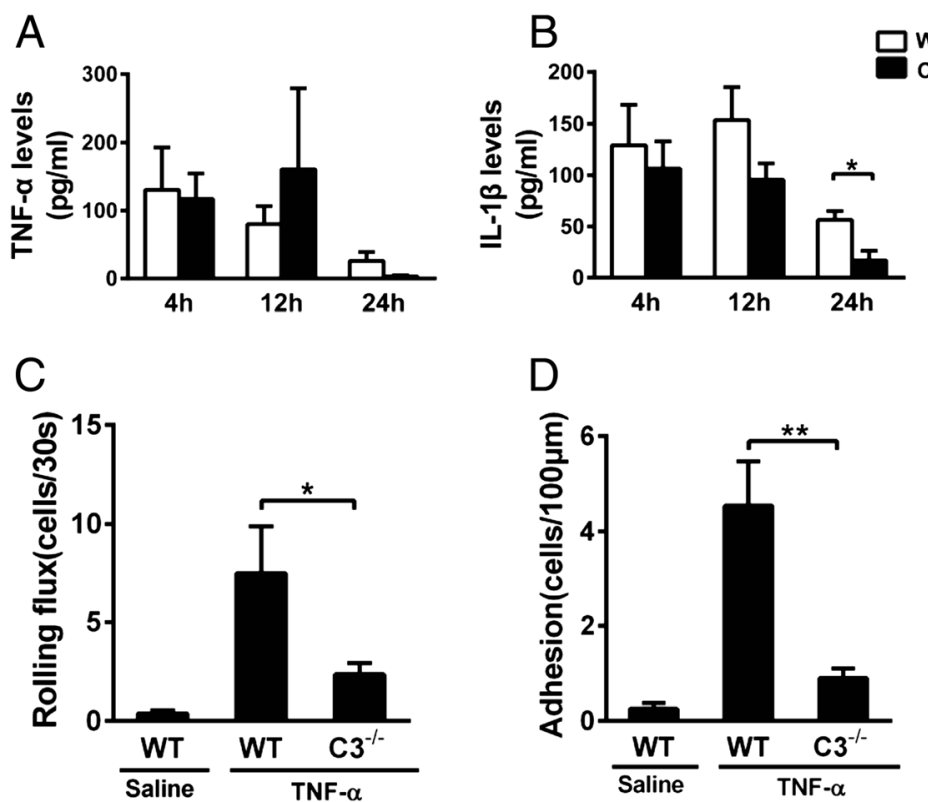

Fig. 6 TNF-a has a synergistic effect with C3 on the induction of leukocyte recruitment in vivo. C3 $3^{-1-}$ mice and WT C57BL/6J mice were treated i.C.V. with LPS, and TNF-a (a) and IL-1 $\beta$ (b) concentrations in the brain extracts were then measured using ELISA. WT C57BL/6J mice and C3 ${ }^{-/-}$ mice were treated i.c.v. with TNF-a $(0.2 \mu \mathrm{g})$, and intravital microscopy was performed to examine leukocyte recruitment in WT C57BL/6J mice and $\mathrm{C}^{-1-}$ mice at $4 \mathrm{~h}$ after i.c.v. TNF-a injection. The data for leukocyte rolling flux (c) and adhesion (d) are shown as the means \pm SEM. ${ }^{*} P<0.05$, ${ }^{*} P<0.01 ; n \geq 4$ for all groups

suggests that there may be a synergistic effect of C3 with TNF- $\alpha$ on brain endothelial cell activation in vivo.

\section{C3a induces brain endothelial cell activation and adhesion molecule expression}

To further confirm the role of C3a in cerebral endothelial activation, primary brain endothelial cells were isolated from WT C57/BL6J mice and treated with C3a $(200 \mathrm{ng} / \mathrm{ml})$ and TNF- $\alpha(1 \mathrm{ng} / \mathrm{ml})$ for $4 \mathrm{~h}$. As expected, TNF- $\alpha$ stimulated the increased ICAM-1 and VCAM-1 expression in brain endothelial cells from WT mice. C3a induced ICAM-1 and VCAM-1 expression in brain endothelial cells from WT mice but not $\mathrm{C}_{3} \mathrm{aR}^{-/-}$mice (Fig. 7a). Further, C3a (200 ng/ml) and TNF- $\alpha(1 \mathrm{ng} / \mathrm{ml})$ have a synergistic effect on inducing the expression of ICAM-1 and VCAM-1 in primary cerebral endothelial cells (Fig. 7a). In addition, C3a induced the phosphorylation of p38 mitogen-activated protein kinase (MAPK) and NF- $\mathrm{kB}$ in brain endothelial cells from the WT mice (Fig. 7b). Therefore, C3a stimulates the expression of adhesion molecules in primary cerebral endothelial cells in vitro.

\section{Discussion}

The brain has long been considered to be an immuneprivileged organ. However, it is well appreciated that the brain can respond to pathogens and danger signals; in particular, resident glial cells generate inflammatory cytokines and chemokines [39, 40], which in turn activate endothelial cells to recruit immune cells into the brain [15]. In CNS inflammation, elevated levels of C3 in CSF in humans and mice with bacterial meningitis have been previously reported [41, 42]. In addition, several studies have shown critical roles for complement components in brain inflammation and reduced leukocyte recruitment in complement-deficient animals [43, 44]. However, the detailed mechanism underlying the role of the complement system in immune-cell recruitment into the brain remains unknown. In the present study, we used complement-deficient mice to evaluate the contributions of the complement component $\mathrm{C} 3$ in leukocyte recruitment into the brain during inflammation. Our results demonstrated that C3 plays an essential role in cerebral endothelial activation and contributes to neutrophil recruitment into the brain parenchyma.

Complement activation occurs via three different pathways: classical, alternative, and the mannose-binding lectin (MBL) pathways. As the most abundant component of the complement system, C3 is indispensable for all three pathways of complement activation [45]. The cleavage and activation of $\mathrm{C} 3$ initiate the membrane attack pathway, through the formation of the membrane attack complex (MAC), consisting of $\mathrm{C} 5 \mathrm{~b}, \mathrm{C} 6, \mathrm{C} 7, \mathrm{C} 8$, and polymeric C9. Neutrophil infiltration into the brain after i.c.v. LPS injection was compromised in $\mathrm{C}^{-/-}$mice but not in $\mathrm{C6}^{-/-}$ mice, suggesting that reduced neutrophil recruitment is 


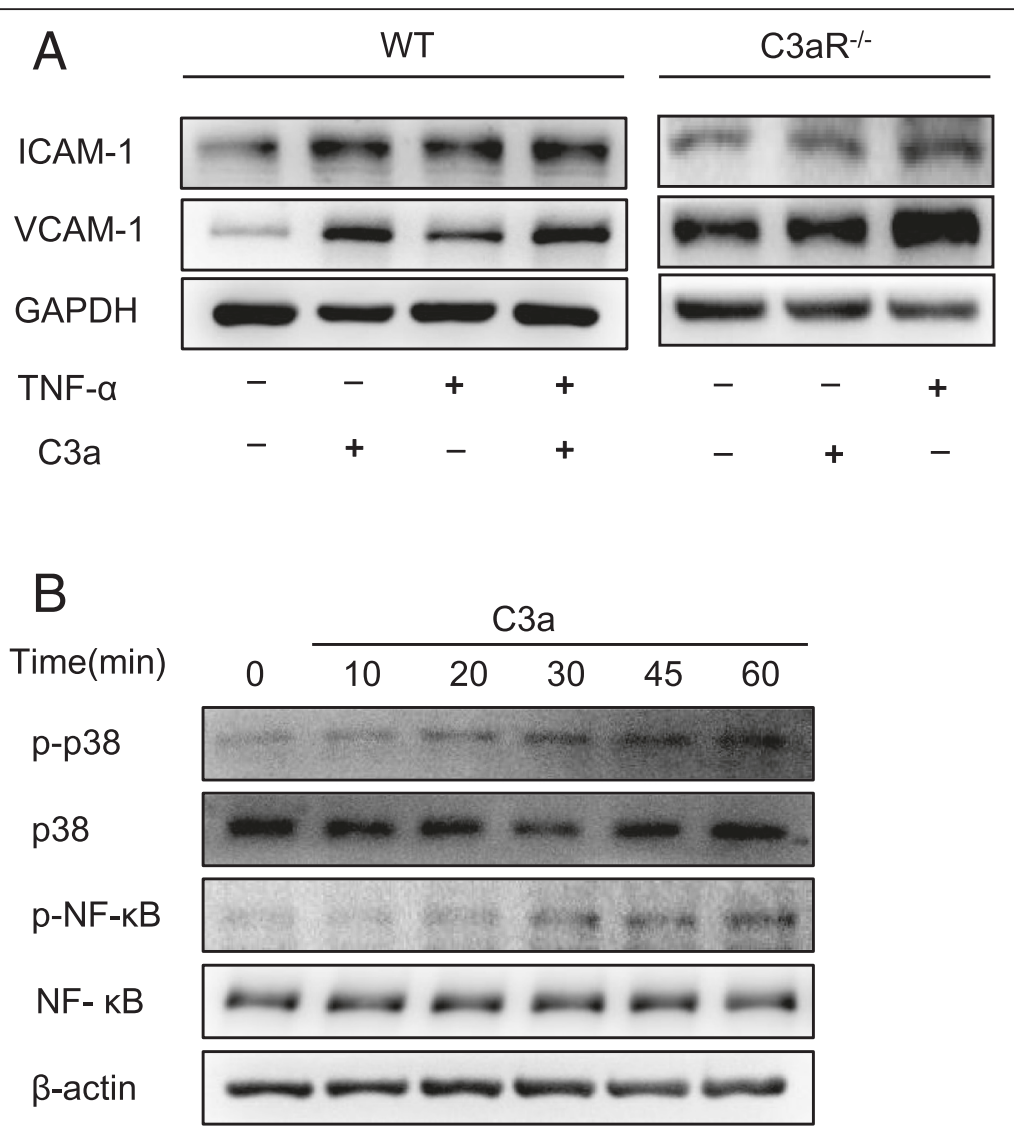

Fig. 7 C3a stimulates primary brain endothelial activation and signaling pathways in vitro. Primary brain microvascular endothelial cells of WT C57BL/6J mice and C3aR ${ }^{-1-}$ mice (a) were stimulated with either vehicle, C3a (200 ng/ml), TNF-a (1 ng/ml), or C3a (200 ng/ml) plus TNF-a (1 ng/ $\mathrm{ml}$ ) for $4 \mathrm{~h}$, and the cell lysates were then analyzed for the expression of adhesion molecules using Western blotting. b Primary brain endothelial cells from wild-type mice were incubated with either vehicle or C3a for the indicated time points, and phosphorylated forms of p65 NF-kB and the MAPK p38 in cell lysates were then detected using Western blotting. Images are representative of four experiments

not dependent on C6 or MAC assembly. The activation of complement system has broad potential biological consequences, because C3a functions as a chemotactic factor for many types of immune cells [46]. Additionally, we observed significant increased expression of $\mathrm{KC}(\mathrm{CXCL1})$ and MIP-2(CXCL2) in the brains of $\mathrm{C}^{-/-}$mice (data not shown), and this expression likely provides sufficient chemotactic strength for recruiting neutrophils into the brain parenchyma. Therefore, a lack of chemotactic traction does not explain the inhibition of neutrophil recruitment into the $\mathrm{CNS}$ in $\mathrm{C}^{-1-}$ mice.

Microglial involvement and endothelial activation are two key steps in recruiting neutrophils into the CNS during LPS-induced inflammation. Microglia are the dominant sentinel cells for the detection of bacterial products, and these cells release TNF- $\alpha$, which activates the endothelium and facilitates leukocyte rolling, adherence, and recruitment into the CNS parenchyma [47]. In previous studies, we showed that activated glial cells control neutrophil recruitment by secreting TNF- $\alpha$ and CXCL1 $[15,16]$. It has recently been reported that C3 is involved in microglial activation and priming under various CNS inflammatory conditions [48]. Additionally, complement $\mathrm{C} 1 \mathrm{q}$ and $\mathrm{C} 3$ are critical for the innate immune response to Streptococcus pneumoniae in the $\mathrm{CNS}$, and $\mathrm{C}^{-1-}$ mice were shown to display reduced expression of IL-1 $\beta$, IL-12 and MIP- $1 \gamma$ in the CNS in a meningitis animal model [28]. In the present study, only a reduction in the IL-1 $\beta$ level at $24 \mathrm{~h}$ was detected in the brain, which is consistent with the findings of previous studies. The levels of KC and MIP-2, essential neutrophil-attracting chemokines, were higher in $\mathrm{C}^{-/-}$ mice than WT mice at $24 \mathrm{~h}$ post-LPS injection (data not shown). In contrast, TNF- $\alpha$, a key cytokine for the stimulation of endothelial activation and subsequent leukocyte recruitment, did not decrease significantly in $\mathrm{C}^{-/-}$animals. Taken together, these results indicate that C3 deficiency did not affect glial cell activation. Upon LPS stimulation, inflammatory cytokines and chemokines were highly produced in these complement-deficient mice, indicating that reduced recruitment might not reflect the compromised glial activation. 
The importance of endothelial cell activation in leukocyte recruitment has been well documented $[49,50]$. In a previous study, we reported that a significant increase in TNF- $\alpha$ released from microglia avidly activates the endothelium, causing an increase in adhesion molecule expression and leukocyte recruitment [15]. Upon LPS injection, the glial cells in $\mathrm{C} 3^{-/-}$mice produced high levels of TNF- $\alpha$ in the brain parenchyma, although significant reduction in leukocyte rolling and adhesion was observed in the brain microvasculature. Accordingly, the expression levels of adhesion molecules (P-selectin, E-selectin, and VCAM-1), which facilitate leukocyte rolling and adherence in brain postcapillary venules, were downregulated in these mice. Clearly, C3 deficiency affected endothelial activation and significantly reduced E-selectin and VCAM-1 expression in $\mathrm{C}^{-/-}$animals, even in the presence of high levels of TNF$\alpha$, indicating that $\mathrm{C} 3$ has synergistic effects with TNF- $\alpha$ on endothelial activation in vivo. C3a stimulates cerebral endothelial activation through its $G$ protein-coupled receptor C3aR. However, TNF- $\alpha$ was able to directly activate endothelial cells to express adhesion molecules in the absence of C3. The mechanism for this discrepancy between the in vivo and in vitro observations remains to be elucidated.

The liver is a primary source of complement components [51], most of which remain within the circulation. Additionally, it has been reported that the local synthesis of complement components in resident cells in the CNS plays an essential role during CNS inflammation [52, 53]. The complement components detected in the CNS are primarily derived from two sources: (1) complement components are locally synthesized from different types of neural glial cells in the brain $[54,55]$; and (2) the BBB is not impermeable, and complement components can bypass the barriers and penetrate into the brain parenchyma within $12 \mathrm{~h}$ after BBB integrity has been compromised. C3 was only detected in the CNS $12 \mathrm{~h}$ after LPS injection. Thus, considering that endothelial cell activation and leukocyte rolling and adhesion were activated at $4 \mathrm{~h}$ postinjection, when the $\mathrm{C} 3$ level in the brain homogenate was nearly undetectable, C3 from the brain parenchyma was unlikely to facilitate endothelial activation and leukocyteendothelial interactions. We propose that complement components from the circulation may play a major role in endothelial activation for the following two reasons. First, endothelial activation was dependent on the expression of adhesion molecules on the CNS endothelium. Notably, most of the adhesion molecules were expressed on the luminal side of the CNS endothelium. Thus, it would be easier for $\mathrm{C} 3$ in the circulation, rather than factors secreted from the CNS, to mediate the expression of adhesion molecules on the luminal side of the brain endothelium. Second, C3 levels in the circulation were much higher than those in the brain, even after a 100-fold dilution of the plasma samples. Additionally, CVF depletes the complements in the circulation via C3 activation and cleavage. This could potentially cause a massive increase in C3a levels. However, the increase of C3a might not last for a long period and might be depleted from circulation in a very short time. We have already measured levels of $\mathrm{C} 3 \mathrm{a}$ at $4 \mathrm{~h}$ (the time point for endothelial activation) and $8 \mathrm{~h}$ after CVF injection and detected minimum amount of C3a in the circulation. Further, CVF treatment significantly reduced brain endothelial activation. Taken together, these results indicate that it is the $\mathrm{C} 3$ in the circulation that facilitates brain endothelial activation.

\section{Conclusions}

Our results showed impaired neutrophil recruitment to the brain vasculature in $\mathrm{C}^{-/-}$mice and $\mathrm{C}^{-1} \mathrm{aR}^{-/-}$mice. Endothelial cell activation in these mice was affected by C3 deficiency. Our present study also reveals that the complement component C3a plays a critical role in brain endothelial activation and the expression of adhesion molecules, such as E-selectin and VCAM-1, in response to local LPS administration. Moreover, we provide the first evidence of a synergistic effect between $\mathrm{C} 3$ and TNF- $\alpha$ for the activation of brain endothelial cells in vivo. Our findings suggest that blocking or preventing complement activation is a promising approach for suppressing leukocyte recruitment and endothelial activation in inflammatory diseases in the brain.

\section{Additional files}

Additional file 1: Time-lapse recordings of the intravascular rolling and adhesion of leukocytes in WT C57BL/6J mice after intraventricular LPS injection (4 h). Rolling leukocytes were defined as those cells moving at a velocity less than that of erythrocytes. Cells were considered adherent if they remained stationary for at least $30 \mathrm{~s}$ in a distance of $100 \mu \mathrm{m}$. (MOV 798 kb)

Additional file 2: Time-lapse recordings demonstrating the lack of the intravascular rolling and adhesion of leukocytes in $\mathrm{C}^{-/-}$mice after intraventricular LPS injection (4 h). Rolling leukocytes were defined as those cells moving at a velocity less than that of erythrocytes. Cells were considered adherent if they remained stationary for at least $30 \mathrm{~s}$ in a distance of $100 \mu \mathrm{m}$. (MOV $750 \mathrm{~kb}$ )

Additional file 3: Time-lapse recordings of the intravascular rolling and adhesion of leukocytes in $\mathrm{C}^{-/-}$mice after intraventricular LPS injection (4 h). Rolling leukocytes were defined as those cells moving at a velocity less than that of erythrocytes. Cells were considered adherent if they remained stationary for at least $30 \mathrm{~s}$ in a distance of $100 \mu \mathrm{m}$. (MOV 573 kb)

\section{Abbreviations}

BBB: blood-brain barrier; CVF: cobra venom factor; ICAM-1: intercellular cell

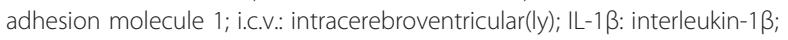
KC: keratinocyte-derived chemokine/CXCL1; KO: knockout;

LPS: lipopolysaccharide; MIP-2: macrophage inflammatory protein-2/CXCL2; NF-kB: nuclear factor-kB; PBS: phosphate-buffered saline; TNF-a: tumor necrosis factor-a; VCAM-1: vascular cell adhesion molecule 1; WT: wild-type; CNS: central nervous system.

Competing interests

The authors declare that they have no competing interests. 


\section{Authors' contributions}

FJW and DYS performed the intravital microscopy and histology experiments. DXD and FJW performed the quantitative PCR and Western blotting experiments. XXZ conducted the cell cultivation experiments. $\mathrm{HZ}$ and QZ conceived the study. HZ wrote the manuscript, and LL and WGH revised the manuscript for important intellectual content. All authors read and approved the final manuscript.

\section{Acknowledgements}

This work was supported through grants from the National Natural Science Foundation of China (81172796, 81373225), the Jiangsu Provincial Natural Science Foundation (BK2011769), and the Research Fund for the Doctoral Program of Higher Education (20133234110005).

\section{Author details}

'Department of Immunology, Nanjing Medical University, 140 Hanzhong Road, Nanjing, JS 210029, China. ${ }^{2}$ Department of Immunology, Chengdu Medical College, Chengdu 610083Sichuan, China. ${ }^{3}$ Shanghai Cancer Center and Institute of Biomedical Science, Shanghai Medical College, Shanghai Cancer Center, Fudan University, Shanghai 200032, China. ${ }^{4}$ Department of Pharmacology, College of Medicine, University of Saskatchewan, Saskatoon, Saskatchewan S7N 5E5, Canada.

Received: 6 November 2015 Accepted: 18 January 2016

Published online: 28 January 2016

\section{References}

1. Niederkorn JY. See no evil, hear no evil, do no evil: the lessons of immune privilege. Nat Immunol. 2006;7:354-9.

2. Carson MJ, Doose JM, Melchior B, Schmid CD, Ploix CC. CNS immune privilege: hiding in plain sight. Immunol Rev. 2006;213:48-65.

3. Woehrl B, Klein M, Rupprecht T, Schmetzer H, Angele B, Häcker H, et al. CXCL16 contributes to neutrophil recruitment to cerebrospinal fluid in pneumococcal meningitis. J Infect Dis. 2010;202:1389-96.

4. Friese MA, Fugger L. T cells and microglia as drivers of multiple sclerosis pathology. Brain. 2007;130:2755-7.

5. Perez-de-Puig I, Miró-Mur F, Ferrer-Ferrer M, Gelpi E, Pedragosa J, Justicia C, et al. Neutrophil recruitment to the brain in mouse and human ischemic stroke. Acta Neuropathol. 2015;129:239-57.

6. Rubio N, Sanz-Rodriguez F. Induction of the CXCL1 (KC) chemokine in mouse astrocytes by infection with the murine encephalomyelitis virus of Theiler. Virology. 2007;358:98-108.

7. García-Ramallo E, Marques T, Prats N, Beleta J, Kunkel SL, Godessart N. Resident cell chemokine expression serves as the major mechanism for leukocyte recruitment during local inflammation. J Immuno. 2002;169: 6467-73.

8. Diab A, Abdalla H, Li HL, Shi FD, Zhu J, Höjberg B, et al. Neutralization of macrophage inflammatory protein 2 (MIP-2) and MIP-1alpha attenuates neutrophil recruitment in the central nervous system during experimental bacterial meningitis. Infect Immun. 1999;67:2590-601.

9. Campbell SJ, Wilcockson DC, Butchart AG, Perry VH, Anthony DC. Altered chemokine expression in the spinal cord and brain contributes to differential interleukin-1beta-induced neutrophil recruitment. J Neurochem. 2002;83:432-41.

10. Simmons SB, Liggitt D, Goverman JM. Cytokine-regulated neutrophil recruitment is required for brain but not spinal cord inflammation during experimental autoimmune encephalomyelitis. J Immunol. 2014;193:555-63.

11. Mantovani A, Cassatella MA, Costantini C, Jaillon S. Neutrophils in the activation and regulation of innate and adaptive immunity. Nat Rev Immunol. 2011;11:519-31.

12. Steinbach K, Piedavent M, Bauer S, Neumann JT, Friese MA. Neutrophils amplify autoimmune central nervous system infiltrates by maturing local APCs. J Immunol. 2013;191:4531-9.

13. Kerfoot SM, Kubes P. Overlapping roles of P-selectin and alpha 4 integrin to recruit leukocytes to the central nervous system in experimental autoimmune encephalomyelitis. J Immunol. 2002;169:1000-6.

14. Howe CL, Lafrance-Corey RG, Sundsbak RS, Lafrance SJ. Inflammatory monocytes damage the hippocampus during acute picornavirus infection of the brain. J Neuroinflammation. 2012;9:50.
15. Zhou H, Lapointe BM, Clark SR, Zbytnuik L, Kubes P. A requirement for microglial TLR4 in leukocyte recruitment into brain in response to lipopolysaccharide. J Immunol. 2006;177:8103-10.

16. Wu F, Zhao $Y$, Jiao $T$, Shi $D$, Zhu X, Zhang M, et al. CXCR2 is essential for cerebral endothelial activation and leukocyte recruitment during neuroinflammation. J Neuroinflammation. 2015;12:98.

17. Merrill JE, Benveniste EN. Cytokines in inflammatory brain lesions: helpful and harmful. Trends Neurosci. 1996;19:331-8.

18. Rao RM, Yang L, Garcia-Cardena G, Luscinskas FW. Endothelial-dependent mechanisms of leukocyte recruitment to the vascular wall. Circ Res. 2007:101:234-47.

19. Markiewski MM, Lambris JD. The role of complement in inflammatory diseases from behind the scenes into the spotlight. Am J Pathol. 2007;171:715-27.

20. Brennan FH, Anderson AJ, Taylor SM, Woodruff TM, Ruitenberg MJ. Complement activation in the injured central nervous system: another dualedged sword? J Neuroinflammation. 2012;9:137.

21. Veerhuis R, Nielsen HM, Tenner AJ. Complement in the brain. Mol Immunol. 2011:48:1592-603

22. Stahel PF, Frei K, Eugster HP, Fontana A, Hummel KM, Wetsel RA, et al. TNF-alpha-mediated expression of the receptor for anaphylatoxin C5a on neurons in experimental Listeria meningoencephalitis. J Immunol. 1997;159:861-9.

23. Davoust N, Jones J, Stahel PF, Ames RS, Barnum SR. Receptor for the C3a anaphylatoxin is expressed by neurons and glial cells. Glia. 1999:26:201-11.

24. Woodruff TM, Crane JW, Proctor LM, Buller KM, Shek AB, de Vos K, et al. Therapeutic activity of $C 5$ a receptor antagonists in a rat model of neurodegeneration. FASEB J. 2006;20:1407-17.

25. Arumugam TV, Woodruff TM, Lathia JD, Selvaraj PK, Mattson MP, Taylor SM. Neuroprotection in stroke by complement inhibition and immunoglobulin therapy. Neuroscience. 2009;158:1074-89.

26. Hua Y, Xi G, Keep RF, Hoff JT. Complement activation in the brain after experimental intracerebral hemorrhage. J Neurosurg. 2000;92:1016-22.

27. Yang S, Nakamura T, Hua Y, Keep RF, Younger JG, He Y, et al. The role of complement C3 in intracerebral hemorrhage-induced brain injury. J Cereb Blood Flow Metab. 2006:26:1490-5.

28. Rupprecht TA, Angele B, Klein M, Heesemann J, Pfister HW, Botto M, et al. Complement $\mathrm{C} 1 \mathrm{q}$ and $\mathrm{C} 3$ are critical for the innate immune response to Streptococcus pneumoniae in the central nervous system. J Immunol. 2007;178:1861-9.

29. Mehlhop E, Whitby K, Oliphant T, Marri A, Engle M, Diamond MS. Complement activation is required for induction of a protective antibody response against West Nile virus infection. J Virol. 2005;79:7466-77.

30. Woehrl B, Brouwer MC, Murr C, Heckenberg SG, Baas F, Pfister HW, et al. Complement component 5 contributes to poor disease outcome in humans and mice with pneumococcal meningitis. J Clin Invest. 2011;121:3943-53.

31. Johnson RW, Gheusi G, Segreti S, Dantzer R, Kelley KW. C3H/HeJ mice are refractory to lipopolysaccharide in the brain. Brain Res. 1997;752:219-26.

32. Koedel U, Rupprecht T, Angele B, Heesemann J, Wagner H, Pfister HW, et al. MyD88 is required for mounting a robust host immune response to Streptococcus pneumoniae in the CNS. Brain. 2004;127:1437-45.

33. Szalai AJ, Briles DE, Volanakis JE. Role of complement in C-reactive-proteinmediated protection of mice from Streptococcus pneumoniae. Infect Immun. 1996;64:4850-3.

34. Cowell RM, Plane JM, Silverstein FS. Complement activation contributes to hypoxic-ischemic brain injury in neonatal rats. J Neurosci. 2003;23:9459-68.

35. Kadl A, Leitinger $\mathrm{N}$. The role of endothelial cells in the resolution of acute inflammation. Antioxid Redox Signal. 2005;7:1744-54

36. Pober JS, Sessa WC. Evolving functions of endothelial cells in inflammation. Nat Rev Immunol. 2007;7:803-15.

37. Schraufstatter IU, Trieu K, Sikora L, Sriramarao P, DiScipio R. Complement c3a and c5a induce different signal transduction cascades in endothelial cells. J Immunol. 2002;169:2102-10.

38. Ducruet AF, Hassid BG, Mack WJ, Sosunov SA, Otten ML, Fusco DJ, et al. C3a receptor modulation of granulocyte infiltration after murine focal cerebral ischemia is reperfusion dependent. J Cereb Blood Flow Metab. 2008;28:1048-58.

39. Hanisch UK. Microglia as a source and target of cytokines. Glia. 2002:40:140-55.

40. Kremlev SG, Roberts RL, Palmer C. Differential expression of chemokines and chemokine receptors during microglial activation and inhibition. J Neuroimmunol. 2004;149:1-9. 
41. Stahel PF, Nadal D, Pfister HW, Paradisis PM, Barnum SR. Complement C3 and factor B cerebrospinal fluid concentrations in bacterial and aseptic meningitis. Lancet. 1997;349:1886-7.

42. Stahel PF, Barnum SR. Bacterial meningitis: complement gene expression in the central nervous system. Immunopharmacology. 1997;38:65-72.

43. Lister KJ, Hickey MJ. Immune complexes alter cerebral microvessel permeability: roles of complement and leukocyte adhesion. Am J Physiol Heart Circ Physiol. 2006;291:H694-704.

44. Prodeus AP, Zhou X, Maurer M, Galli SJ, Carroll MC. Impaired mast celldependent natural immunity in complement C3-deficient mice. Nature. 1997:390:172-5.

45. Mastellos D, Morikis D, Isaacs SN, Holland MC, Strey CW, Lambris JD. Complement: structure, functions, evolution, and viral molecular mimicry. Immunol Res. 2003;27:367-86.

46. Discipio RG, Daffern PJ, Jagels MA, Broide DH, Sriramarao P. A comparison of C3a and C5a-mediated stable adhesion of rolling eosinophils in postcapillary venules and transendothelial migration in vitro and in vivo. J Immunol. 1999;162:1127-36.

47. D'Mello C, Le T, Swain MG. Cerebral microglia recruit monocytes into the brain in response to tumor necrosis factoralpha signaling during peripheral organ inflammation. J Neurosci. 2009;29:2089-102.

48. Ramaglia V, Hughes TR, Donev RM, Ruseva MM, Wu X, Huitinga I, et al. C3-dependent mechanism of microglial priming relevant to multiple sclerosis. Proc Natl Acad Sci USA. 2012;109:965-70.

49. Andonegui G, Bonder CS, Green F, Mullaly SC, Zbytnuik L, Raharjo E, et al. Endothelium-derived Toll-like receptor-4 is the key molecule in LPS-induced neutrophil sequestration into lungs. J Clin Invest. 2003;111:1011-20.

50. Zhou $\mathrm{H}$, Andonegui $\mathrm{G}$, Wong $\mathrm{CH}$, Kubes P. Role of endothelial TLR4 for neutrophil recruitment into central nervous system microvessels in systemic inflammation. J Immunol. 2009;183:5244-50.

51. Qin X, Gao B. The complement system in liver diseases. Cell Mol Immunol. 2006;:333-40.

52. Rozovsky I, Morgan TE, Willoughby DA, Dugichi-Djordjevich MM, Pasinetti GM, Johnson SA, et al. Selective expression of clusterin (SGP-2) and complement $\mathrm{C} 1 \mathrm{qB}$ and $\mathrm{C} 4$ during responses to neurotoxins in vivo and in vitro. Neuroscience. 1994;62:741-58.

53. Veerhuis R, Janssen I, Hoozemans JJ, De Groot CJ, Hack CE, Eikelenboom P. Complement c1-inhibitor expression in Alzheimer's disease. Acta Neuropathol. 1998:96:287-96.

54. Lévi-Strauss M, Mallat M. Primary cultures of murine astrocytes produce C3 and Factor B, two components of the alternative pathway of complement activation. J Immunol. 1987;139:2361-66.

55. Gasque P, Fontaine M, Morgan BP. Complement expression in human brain. Biosynthesis of terminal pathway components and regulators in human glial cells and cell lines. J Immunol. 1995;154:4726-33.

\section{Submit your next manuscript to BioMed Central and we will help you at every step:}

- We accept pre-submission inquiries

- Our selector tool helps you to find the most relevant journal

- We provide round the clock customer support

- Convenient online submission

- Thorough peer review

- Inclusion in PubMed and all major indexing services

- Maximum visibility for your research

Submit your manuscript at www.biomedcentral.com/submit

C Biomed Central 